\title{
Erythema Nodosum due to Warfarin
Treatment in Pulmonary Thromboembolism: A Case Report
}

\author{
Warfarin Tedavisine Bağlı Eritema Nodosum Gelişen Pulmoner \\ Tromboemboli Olgusu
}

Derya Yenibertiz, Berna Akıncı Özyürek, Yurdanur Erdoğan

\section{Abstract}

The most common and important side-effect of warfarin treatment is bleeding. Erythema nodosum, in the form of painful, erythematous nodules in the dermal and subcutaneous tissues, is not a known side-effect of warfarin. In this case, we report on erythema nodosum occurring as a side-effect of warfarin treatment. A 49-year-old female patient was treated for pulmonary thromboembolism after multiple lesions emerged identified as erythema nodosum in a dermatology consultation that were interpreted as a possible side-effect of warfarin treatment. It was concluded that erythema nodosum may present as a side-effect of warfarin.

Key words: Pulmonary thromboembolism, warfarin, erythema nodosum.

\section{Özet}

Warfarin tedavisine bağlı en sık ve en önemli yan etki kanamadır. Dermal ve subkutan dokularda ağrılı, eritemli nodüllerden oluşan eritema nodozum warfarinin bilinen bir yan etkisi değildir. Warfarine tedavisine bağlı gelişen eritema nodozum olgumuzu sunmayı amaçladık. Pulmoner tromboemboli tedavisi başlanan 49 yaşında kadın hastada warfarin kullanımına bağlı dermatoloji konsültasyonu ile eritema nodozum olarak tanımlanan çok sayıda lezyon saptandı. Warfarin tedavisine bağlı bir yan etki olarak eritema nodozum görülebileceğini vurgulamak istedik.

Anahtar Sözcükler: Pulmoner tromboemboli, warfarin, eritema nodozum.

Sağlık Bilimleri Üniversitesi, Atatürk Göğüs Hastalıkları ve Göğüs Cerrahisi Eğitim Araştırma Hastanesi, Ankara

University of Health Sciences, Ataturk Chest Diseases and Chest Surgery Training and Research Hospital, Ankara, Turkey

Submitted (Başvuru tarihi): 21.09.2019 Accepted (Kabul tarihi): 16.01.2020

Correspondence (iletişim): Berna Akıncı Özyürek, Sağlık Bilimleri Üniversitesi, Atatürk Göğüs Hastalıkları ve Göğüs Cerrahisi Eğitim Araştırma Hastanesi, Ankara

e-mail: drberna_1982@yahoo.com 
Pulmonary thromboembolism (PTE) is the result of a clot in the pulmonary artery or in one of its branches, and is associated with high morbidity and mortality. Patientspecific treatment is guided by signs and symptoms, bleeding risk and comorbidities. Warfarin sodium - a vitamin $\mathrm{K}$ antagonist - is an effective option for the treatment of PTE, despite its narrow therapeutic index, its wide inter-patient dosing variability, its predisposition to drug and food interactions, and the need for close monitoring of the intensity of the anticoagulation effect using the international normalized ratio (INR). The most common and important side effect of warfarin treatment is bleeding (1). Several adverse skin manifestations have been associated with the use of oral anticoagulants, ranging from ecchymosis and purpura, hemorrhagic necrosis and maculopapular vesicular urticarial eruptions, to purple toes (2). While skin necrosis has been mentioned as the most common dermatological side-effect of warfarin in literature (2-7), we could find no studies in literature identifying erythema nodosum as a warfarin-related sideeffect.

In this case, we report that erythema nodosum may occur as a side effect of warfarin treatment.

\section{CASE}

A 49-year-old, non-smoking, female patient applied to our hospital emergency department with a sudden onset of dyspnea and cough. The patient reported no other symptoms, such as fever, malaise, fatigue, weight loss, dysuria or sputum, and there were no signs of infection in the patient. Upon hospitalization, thrombus was detected in the subsegmentary arteries at the level of both posterobasal segments in the lungs in a thorax computed tomography angiography (Figure 1). The patient had neither identified history of chronic medical disease nor a remarkable family medical history. Her physical examination was normal and all laboratory parameters, include C-reactive protein and white blood cells, were normal with the exception of a raised $d$-dimer. Low molecular weight heparin and warfarin treatment were started simultaneously; the patient was treated with no other drugs. When the INR value reached the desired range due to the effective dose of warfarin, the low molecular weight heparin was stopped and treatment continued with warfarin. On the 7th day of warfarin treatment, multiple painful, swollen, nodular indurations emerged all over the body (Figure 2 and 3). The patient was passed to the dermatology and allergy clinic, and the lesions were linked to the warfarin treatment. Warfarin was stopped, and treat- ment for erythema nodosum was carried out, as per the dermatologist's suggestion. The skin lesions regressed on follow-up.

\section{DISCUSSION}

Erythema nodosum is a form of acute nodular septal panniculitis, characterized by the sudden onset of erythematous, firm, solid, deep nodules or plaques that are painful on palpation, and localized mainly on the extensor surfaces of the legs. It occurs more often in women aged 25-40 years, but can be observed at any age (8). Erythema nodosum may be linked to a variety of causes, such as infection, medications, sarcoidosis, pregnancy, inflammatory bowel disease, vaccination, autoimmune disease and malignancy, among others. The condition is idiopathic in approximately $50 \%$ of cases. Diagnosis is generally made clinically, but a biopsy may be required in atypical cases (9). A skin biopsy is generally not necessary if the history and physical signs are suggestive of EN, and the treatment of EN depends on the suspected or documented etiology, if known (10).

Our patient, a woman aged 49-year-old, presented with lesions that were diagnosed as erythema nodosum by a dermatologist. No biopsy was performed as the lesions were considered typical. Most cases of erythema nodosum are self-limited and require no treatment. Bed rest and leg elevation are generally recommended to reduce discomfort. Nonsteroidal anti-inflammatory drugs are the first-line treatment for pain management. The dermatologist started the patient on Colchium Dispert and nonsteroidal anti-inflammatory drugs.

The present study emphasizes the rarity of erythema nodosum as a side-effect of warfarin.

\section{CONCLUSION}

This article reports on a case of erythema nodosum that emerged due to warfarin treatment for a pulmonary thromboembolism

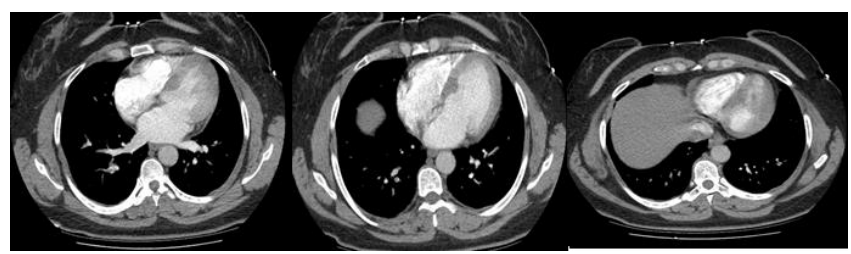

Figure 1: Computed tomography angiography of the thorax 


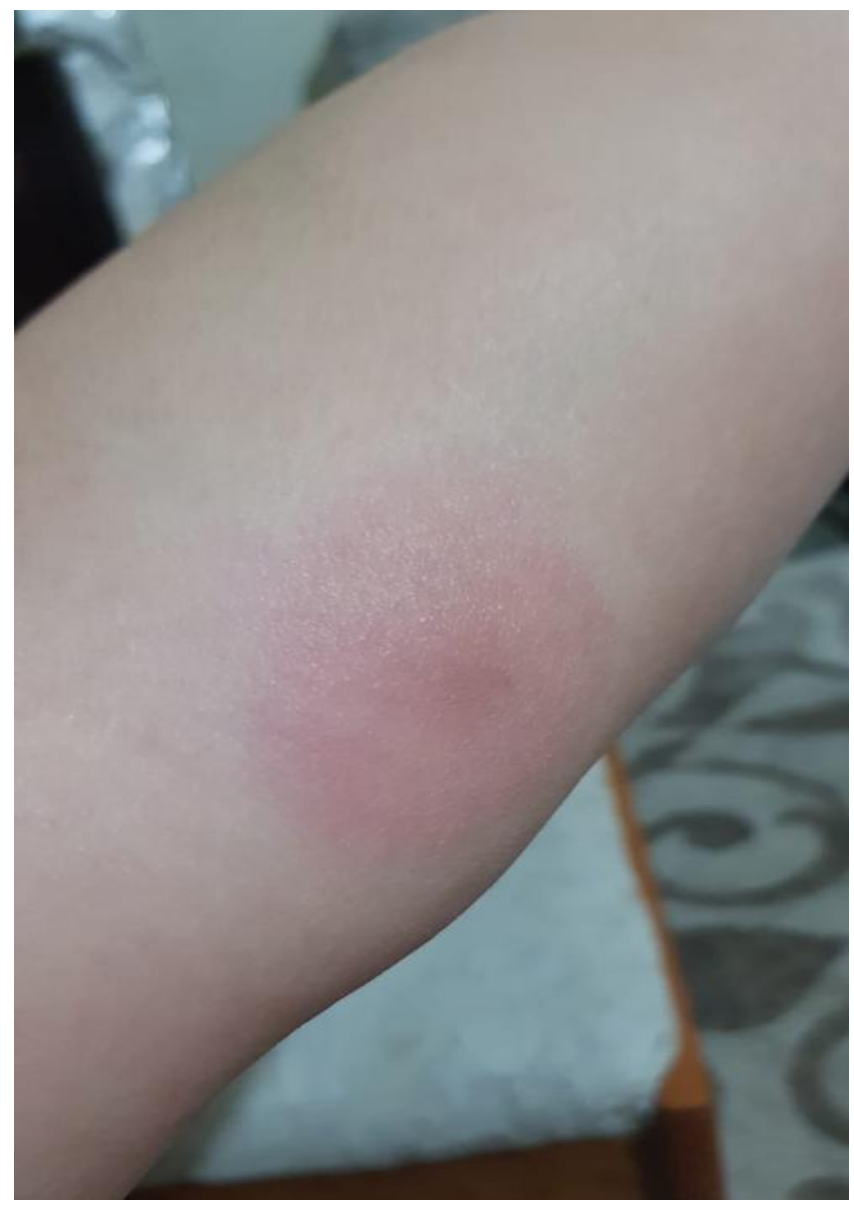

Figure 2: Erythema nodosum on the leg

\section{CONFLICTS OF INTEREST}

None declared.

\section{AUTHOR CONTRIBUTIONS}

Concept - D.Y., B.A.Ö., Y.E.; Planning and Design - D.Y., B.A.Ö., Y.E.; Supervision - D.Y., B.A.Ö., Y.E.; Funding D.Y., B.A.Ö.; Materials - D.Y., B.A.Ö.; Data Collection and/or Processing - D.Y., B.A.Ö.; Analysis and/or Interpretation - E D.Y., B.A.Ö.; Literature Review - D.Y., B.A.Ö.; Writing - D.Y.; Critical Review - D.Y., B.A.Ö.

\section{YAZAR KATKILARI}

Fikir - D.Y., B.A.Ö., Y.E.; Tasarım ve Dizayn - D.Y., B.A.Ö., Y.E.; Denetleme - D.Y., B.A.Ö., Y.E.; Kaynaklar D.Y., B.A.Ö.; Malzemeler - D.Y., B.A.Ö.; Veri Toplama ve/veya İşleme - D.Y., B.A.Ö.; Analiz ve/veya Yorum D.Y., B.A.Ö.; Literatür Taraması - D.Y., B.A.Ö.; Yazıyı Yazan - D.Y.; Eleştirel İnceleme - D.Y., B.A.Ö.

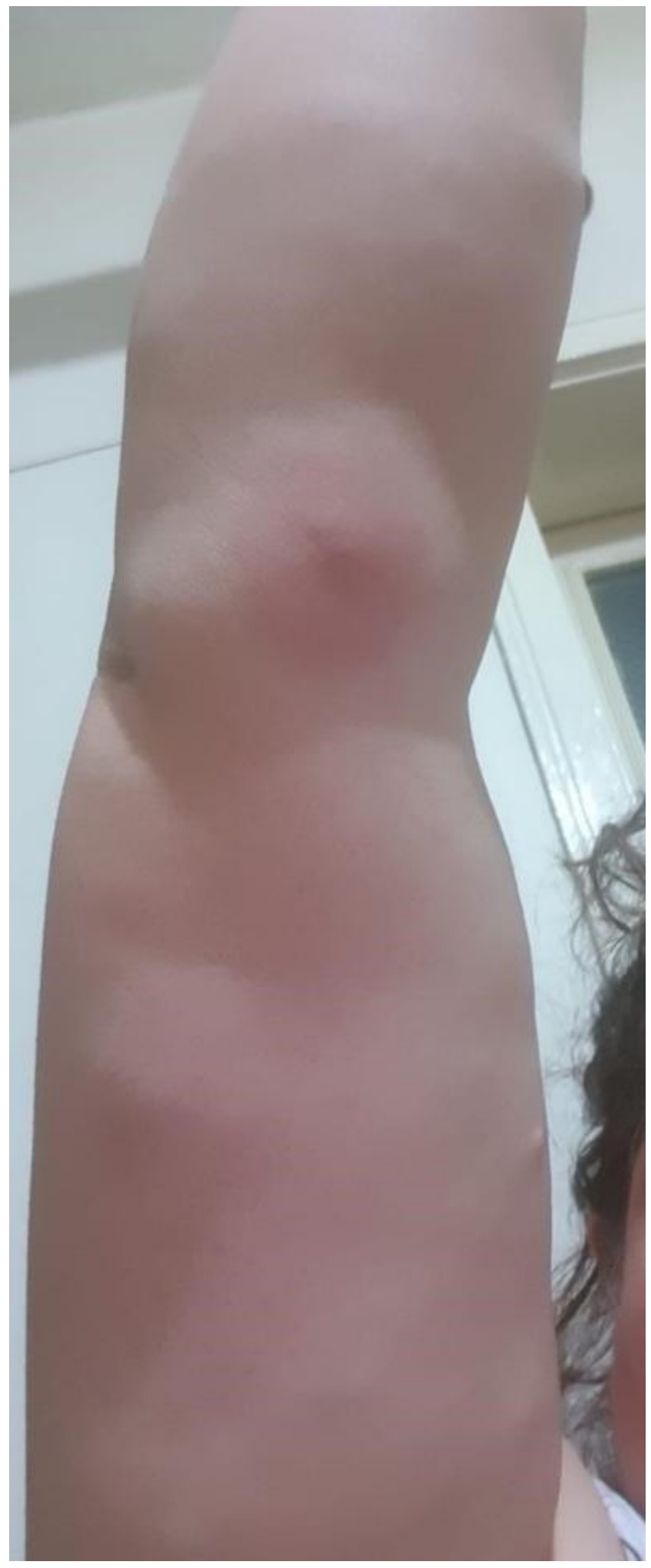

Figure 2: Erythema nodosum on the arm 


\section{REFERENCES}

1. Ageno W, Gallus AS, Wittkowsky A, Crowther M, Hylek EM, Palareti G. Oral anticoagulant therapy: antithrombotic therapy and prevention of thrombosis, 9th ed: American College Of Chest Physicians Evidence- Based Clinical Practice Guidelines. Chest 2012; 141: e44Se88S. [CrossRef]

2. Chan YC, Valenti D, Mansfield AO, Stansby G. Warfarin induced skin necrosis. Br J Surg 2000; 87: 266-72. [CrossRef]

3. Eichhoff G. Warfarin induced skin necrosis within psoriatic plaques Dermatol Online J 2019; 25(6): pii: 13030/qł4gf5r5qk.

4. Tilton C, Livengood S, Hodges J, Marshall J. Warfarininduced skin necrosis in the presence of acute hepatic injury and May-Thurner Syndrome. Hosp Pharm 2019; 54: 130- 4. [CrossRef]

5. Fraga R, Diniz LM, Lucas EA, Emerich PS. Warfarininduced skin necrosis in a patient with protein $S$ deficiency. An Bras Dermatol 2018; 93: 612- 3. [CrossRef]
6. Sklar LR, Messman A. An atypical case of warfarininduced skin necrosis. Clin Pract Cases Emerg Med 2017; 1: 359-61. [CrossRef]

7. Hamada T, Miyake T, Otsuka M, Iwatsuki K. Warfarininduced skin necrosis accompanied by aggravation of vasculitis in a patient with cutaneous arteritis. Int J Dermatol 2017; 56:779-81. [CrossRef]

8. Hafsi W, Badri T. Erythema Nodosum. [Updated 2019 Dec 20]. In: StatPearls [Internet]. Treasure Island (FL): StatPearls Publishing; 2020 Jan-. Available from: https://www.ncbi.nlm.nih.gov/books/NBK470369/

9. Leung $A K C$, Leong KF, Lam JM. Erythema nodosum. World J Pediatr 2018; 14:548-54. [CrossRef]

10. Allen RA. Erythema Nodosum. Clinical Gate Dermatology 18/ 03/ $2015 . \quad$ Available from: https://clinicalgate.com/erythema-nodosum-2/ 